\title{
Risk stratification and prognostic value of serum neutrophil gelatinase-associated lipocalin (sNGAL) in sepsis patients
}

\author{
Ying Wu${ }^{1}$, Chen $\mathrm{Yu}^{2 \otimes}$, Ying Zhou ${ }^{2}$, Zai-Ming He${ }^{1}$, Wei Zhang ${ }^{1}$, Juan Fan ${ }^{1}$ and Ying Sun ${ }^{1}$ \\ 'Department of Emergency Medicine, Liqun Hospital, Putuo District, Shanghai, China; ${ }^{2}$ Department of Nephrology, Tongji Hospital, Tongji \\ University School of Medicine, Shanghai, China
}

\begin{abstract}
Objective: Sepsis is a host response with life-threatening organ dysfunction caused by an infection. Although the overall mortality rate has increased from $30 \%$ to $37 \%$ by the surviving sepsis campaign, it is still not acceptable. Early identification, accurate stratification and appropriate intervention can improve the prognosis. In this study we assessed the risk stratification and prognostic value of serum neutrophil gelatinase-associated lipocalin (sNGAL) as a biomarker in sepsis patients. Methods: A total of 112 sepsis patients (38 patients with sepsis, 41 patients with severe sepsis, 33 patients with septic shock) and 25 healthy controls were enrolled in this study. Serum samples of all patients were collected and frozen before testing. Basic patient information was collected, including age, gender, primary infection, complications, and so on. Results of serum calcitonin, lactic acid, and SOFA score were followed up for 28 days. Results: Levels of serum procalcitonin (PCT), serum lactate, Sequential Organ Failure Assessment (SOFA) score and SNGAL of sepsis patients were significantly higher $(p<0.05)$ than those of controls. The sNGAL level in sepsis patients who were alive on the 28th day of followup was significantly lower $(p<0.05)$ than that of sepsis patients who had died before the 28th day of followup. Multiple logistic regression analysis showed that sNGAL-Oh and lactates were independent risk factors of death due to sepsis within 28 days. At cut-off value of $250 \mathrm{ng} / \mathrm{mL}$, the sensitivity and specificity sNGAL-Oh predicting the 28-day mortality in septic patients were 0.838 and 0.827 , respectively. The sNGAL level in sepsis patients with acute kidney injury (AKI) was significantly higher $(p<0.05)$ than in sepsis patients without AKI. Conclusion: Serum NGAL may contribute to the assessment of the severity of sepsis. Serum NGAL and lactate can be independent risk factors for 28-day mortality in sepsis patients. Serum NGAL has potential of predicting septicAKI.
\end{abstract}

Keyword: sepsis, serum NGAL, AKI, risk stratification, prognostic Received: 24 June, 2021; revised: 13 September, 2021; accepted: 27 October, 2021; available on-line: 28 February, 2022

$\bowtie$ e-mail: yuchen@tongji.edu.cn

Abbreviations: AKI, acute kidney injury; ICU, Intensive Care Unit; PCT, procalcitonin; SOFA, Sequential Organ Failure Assessment; sN$\mathrm{GAL}$, serum neutrophil gelatinase-associated lipocalin

\section{INTRODUCTION}

Sepsis is a kind of infection which is caused by pathogen entering blood circulation. It can progress into severe sepsis, septic shock or even multiple organ failure (Wu et al., 2015). According to the statistics, $1 \%$ of patients in the hospital suffered from sepsis and $25 \%$ of patients in Intensive Care Unit (ICU) came down with sepsis (Zou et al., 2014). Sepsis is one of the major causes to death of patients in the hospital, and its number reaches that of deaths due to myocardial infraction (Cecconi et al., 2018). Sepsis is common in elder patients and the number of sepsis patients will increase with the aging of the population (Hall et al., 2011). Early diagnosis, accurate stratification and proper intervention at an early stage of sepsis are essential in reducing its mortality (Strehlow et al., 2006). Delayed diagnosis and invalid antibacterial treatment were considered as major causes of high incidence and high mortality (Balci et al., 2003). Nowadays, there is no ideal biomarker that helps to diagnose or evaluate severity of sepsis in clinical practice (Wacker et al., 2013). With the development and application of antibiotics, incidence and mortality of sepsis has declined but it is still not satisfying (Dellinger et al., 2013a). According to the statistics, there are over 178 practical biomarkers of sepsis, small part of which are intermediates of inflammation, while most of which are anti-inflammation agents (Liu et al., 2014). There is no consensus as to which kind of biomarker of sepsis is the most accurate in diagnosis and stratification (Behnes et al., 2014).

Neutrophil gelatinase-associated lipocalin (NGAL), with molecular mass of $25 \mathrm{kDa}$, is a type of glycoprotein, and belongs to the lipocalin family (Devarajan, 2010; Cowland \& Borregaard, 1997). NGAL is involved in immune reaction, prostaglandin synthesis and cell proliferation (Flower et al., 2000). NGAL can also represent the vitality of neutrophils, which reflects a systemic infection caused by a systemic immune disease (Bosmann \& Ward, 2013). NGAL can be detected both, in the blood and urine. The main source of urinary NGAL are renal tubular epithelial cells, distal to the tubules (Mori et al., 2005), and serum NGAL comes not only from the damaged renal tubular system, but also from the extrarenal organs (Passov et al., 2019). The difference is that the serum NGAl can reflect the body's systemic inflammatory conditions, while the urinary NGAL has a diagnostic value for acute tubular injury (Feldkamp et al., 2011). Although NGAL has been proven to be an early marker for AKI, results of different studies have not reached a consensus (Zhang et al., 2016).

\section{PATIENTS AND METHOD}

\section{Patients}

Basic information. According to inclusion and exclusion criteria for this study mentioned below, a total of 112 registrations in our hospital from Jul 2015 to Dec 
2016 were enrolled in this study. Out of 112 patients, 58 were male and 54 were female. The average age was $71.82 \pm 8.76$ years old. Basic information included age, gender, primary infection, complications (such as hypertension, diabetes, chronic lung diseases, chronic liver diseases and so on), mechanical ventilation, and hemodialysis. This study has been approved by the ethics committee of the Tongji Hospital. All patients enrolled have signed the informed consent.

Inclusion criteria. According to the "Surviving Sepsis Campaign" (Dellinger et al., 2013a), age of the patients should be over 18 years old and the patient should be able to provide consent by himself/herself.

Exclusion criteria. Patients whose age was lower than 18 years old, pregnant women, malignant tumor patients, patients who suffered from the end-stage renal disease (including long-term dialysis, patients recently undergoing renal transplantation, who had had a kidney transplant before), were diagnosed and suspected to have acute radical glomerulonephritis, acute renal interstitial nephritis or renal vascular disease, were excluded from the study.

Group division. According to the diagnostic criteria for sepsis, 112 patients were divided into three subgroups: sepsis $(n=38)$, severe sepsis $(n=41)$ and septic shock ( $n=33$ ). In the meantime, 25 healthy people who received regular health checks in our hospital were enrolled as the control group.

Sequential organ failure assessment (SOFA). The SOFA score (Lambden et al., 2019) is used to evaluate dysfunction in various organ systems and when the score reaches three it is the cutoff for failure. A higher score means a number of failed organs, which suggests a severer condition and often a higher mortality. Dynamic score can reflect the evolution of the disease and treatment (see Table 1).

\section{Statistical analysis}

IBM SPSS 21.0 was used for statistical analysis. Measurement data that was in line with the normal distribu- tion was shown as mean \pm S.D. $T$-test was adapted in analyzing data from two different groups, and one-way ANOVA was adapted in analyzing data from several different groups. Non-Gauss distributed data was analyzed by a non-parametric test. The count data is expressed as a percentage and two-group data are compared using the chi-square test. Pearson analysis was adapted to assess relationship among sNGAL, PCT, level of serum lactate and SOFA score. Multiple factors logistic regression analysis was adapted to assess relationship between sepsis and age, gender, level of CRP, sNGAL, lactate, PCT and SOFA score. A significant difference was marked when $p$ value is less than 0.05 . $R$ means coefficient of association, SE means standard error, OR means odds ratio, CI means confidence interval, and $t$ value means Significance test value.

\section{RESULTS}

\section{Basic information on sepsis patients at different stages}

All of the basic information including age, gender, complications and other index values is organized in Supplementary Table 1 (at https://ojs.ptbioch.edu.pl/index.php/abp/).

\section{Level of PCT and SNGAL, SOFA score in different subgroups of sepsis}

In comparison to the level of sNGAL of Control Group that is $165.28 \pm 17.34 \mathrm{ng} / \mathrm{ml}$, levels of sNGAL in sepsis, severe sepsis and septic shock were 215.42 \pm 29.35 $\mathrm{ng} / \mathrm{ml}, 243.66 \pm 21.23 \mathrm{ng} / \mathrm{ml}$, and $258.12 \pm 22.65 \mathrm{ng} / \mathrm{ml}$, respectively, and the difference is significant $(p<0.05)$. As time went by, the levels of 24-hour-sNGAL of the three subgroups were $217.82 \pm 25.66,241.07 \pm 24.40$ and $257.27 \pm 25.60$, respectively, which is significantly different $(p<0.05)$. Furthermore, levels of 48 -hour-sNGAL of the three subgroups were $217.82 \pm 25.66,241.07 \pm 24.40$

Table 1. Sequential organ failure assessment (SOFA) score

\begin{tabular}{|c|c|c|c|c|c|c|}
\hline & \multirow{2}{*}{ Index } & \multicolumn{4}{|c|}{ Score } & \multirow[b]{2}{*}{4} \\
\hline & & 0 & 1 & 2 & 3 & \\
\hline \multirow[t]{2}{*}{ Respiration } & $\mathrm{PaO2} / \mathrm{FiO2}$ (Кра) & $>53.33$ & $40 \sim 53.33$ & $26.67 \sim 40$ & $13.33 \sim 26.67$ & $<13.33$ \\
\hline & Assisted respiration & NO & - & - & YES & - \\
\hline Coagulation & Platelet $\left(10^{9} \cdot \mathrm{L}^{-1}\right)$ & $>150$ & $101 \sim 150$ & $51 \sim 100$ & $21 \sim 50$ & $<21$ \\
\hline Hepatic & Bilirubin $\left(\mu \mathrm{mol} \cdot \mathrm{L}^{-1}\right)$ & $<20$ & $20 \sim 32$ & $33 \sim 101$ & $102 \sim 204$ & $>204$ \\
\hline \multirow[t]{5}{*}{ Circulation } & Mean arterial pressure $(\mathrm{mmHg})$ & $\geq 70$ & $<70$ & - & - & - \\
\hline & Dose of Dopamine $\left(\mu \mathrm{g} \cdot \mathrm{kg}^{-1} \cdot \mathrm{min}^{-1}\right)$ & 0 & - & $\leq 5$ & $5 \sim 15$ & $>15$ \\
\hline & Dose of Adrenaline $\left(\mu \mathrm{g} \cdot \mathrm{kg}^{-1} \cdot \mathrm{min}^{-1}\right)$ & 0 & - & - & $\leq 0.1$ & $>0.1$ \\
\hline & Dose of Norepinephrine $\left(\mu \mathrm{g} \cdot \mathrm{kg}^{-1} \cdot \mathrm{min}^{-1}\right)$ & 0 & - & - & $\leq 0.1$ & $>0.1$ \\
\hline & Use of Dobutamine & NO & - & YES & - & - \\
\hline Nervous & GCS score & 15 & $13 \sim 14$ & $10 \sim 12$ & $6 \sim 9$ & $<6$ \\
\hline \multirow[t]{2}{*}{ Renal } & Serum creatinine $\left(\mu \mathrm{mol} \cdot \mathrm{L}^{-1}\right)$ & $<100$ & $100 \sim 170$ & $171 \sim 299$ & $300 \sim 400$ & $>400$ \\
\hline & Urine volume within 24 hours (ml) & - & - & - & $201 \sim 500$ & $<200$ \\
\hline
\end{tabular}


Table 2. Relationship of sNGAL with PCT, lactate and SOFA score

\begin{tabular}{llll}
\hline & items & $r$ & $p$ value \\
\hline & PCT & 0.394 & $<0.01$ \\
\multirow{3}{*}{ SNGAL } & Lactate & 0.710 & $<0.01$ \\
\hline & SOFA & 0.636 & $<0.01$ \\
\hline
\end{tabular}

and $257.27 \pm 25.60$, respectively, which is significantly different $(p<0.05)$.

The $r$ values of PCT level, lactate and the SOFA score with sNGAL in Pearson analysis were 0.394, 0.710 and 0.636 , respectively (see Table 2 ).

\section{Risk factors for death of sepsis within 28 days}

Death of sepsis within 28 days was set as a dependent variable and age, gender, level of PCT, lactate and CRP, level of 0h-sNGAL, 24h-sNGAL and 48h-sNGAL and the SOFA score were analyzed in a logistic regression analysis. Results suggested that age, level of PCT, lactate, 0h-sNGAL, 24h-sNGAL and 48h-sNGAL, as well as the SOFA score were all risk factors for death of sepsis within 28 days (see Table 3).

Table 3. Single factor logistic regression analysis

\begin{tabular}{|c|c|c|c|c|c|}
\hline Item & B & SE & Wals & $p$ & OR $(95 \% \mathrm{Cl})$ \\
\hline age & 0.149 & 0.035 & 17.965 & $<0.01$ & $1.161(1.083 \sim 1.243)$ \\
\hline gender & -0.136 & 0.403 & 0.114 & 0.736 & $0.873(0.396 \sim 1.922)$ \\
\hline Oh-sNGAL & 0.069 & 0.014 & 25.875 & $<0.01$ & $1.072(1.043 \sim 1.101)$ \\
\hline 24h-sNGAL & 0.079 & 0.014 & 30.916 & $<0.01$ & $1.082(1.052 \sim 1.112)$ \\
\hline 48h-sNGAL & 0.082 & 0.014 & 32.016 & $<0.01$ & $1.085(1.055 \sim 1.116)$ \\
\hline PCT & 0.070 & 0.019 & 13.302 & $<0.01$ & $1.073(1.033 \sim 1.114)$ \\
\hline lactate & 0.650 & 0.125 & 4.400 & $<0.01$ & $1.915(0.499 \sim 2.447)$ \\
\hline SOFA & 0.665 & 0.134 & 24.639 & $<0.01$ & $1.944(1.495 \sim 2.527)$ \\
\hline CRP & 0.020 & 0.010 & 4.380 & 0.304 & $1.009(0.992 \sim 1.027)$ \\
\hline
\end{tabular}

$B$ is one coefficient; Wals is one statistical magnitude.

Table 4. Sensitivity and specificity of sNGAL-Oh and lactate predicting 28-day mortality in septic patients

\begin{tabular}{lllllll}
\hline Items & AUC-ROC & $p$ & Cutoff & Sensitivity & Specificity & Cl (95\%) \\
\hline sNGALOh & 0.873 & $<0.05$ & 250 & 0.838 & 0.827 & $(0.800 \sim 0.946)$ \\
\hline lactate & 0.899 & $<0.05$ & 6.6 & 0.892 & 0.653 & $(0.842 \sim 0.957)$ \\
\hline
\end{tabular}

Table 5. Levels of creatine, sNGAL, PCT and lactate, and SOFA score in sepsis with(out) AKI patients

\begin{tabular}{|c|c|c|c|c|}
\hline \multirow{2}{*}{ Items } & Sepsis without AKI & Sepsis with AKI & \multirow{2}{*}{$t$} & \multirow{2}{*}{$p$} \\
\hline & $n=46$ & $\mathrm{n}=11$ & & \\
\hline \multicolumn{5}{|l|}{ Creatine } \\
\hline Oh (umol/l) & $88.71 \pm 18.13$ & $88.68 \pm 18.22$ & -0.004 & 0.997 \\
\hline 48h (umol/l) & $82.21 \pm 11.31$ & $150.18 \pm 23.41$ & -9.369 & 0.000 \\
\hline \multicolumn{5}{|l|}{ sNGAL } \\
\hline Oh (ng/ml) & $217.48+27.08$ & $245.09+26.03$ & -3.060 & 0.007 \\
\hline $24 \mathrm{~h}(\mathrm{ng} / \mathrm{ml})$ & $219.00+25.66$ & $243.91 \pm 24.65$ & -2.987 & 0.009 \\
\hline $48 \mathrm{~h}(\mathrm{ng} / \mathrm{ml})$ & $222.70 \pm 22.16$ & $259.00 \pm 24.36$ & -4.516 & 0.000 \\
\hline РCT (ng/ml) & $12.00+5.68$ & $12.36 \pm 5.55$ & 0.194 & 0.849 \\
\hline Lactate $(\mathrm{mmol} / \mathrm{l})$ & $4.33 \pm 2.38$ & $6.05 \pm 3.61$ & -1.499 & 0.159 \\
\hline SOFA score & $5.02 \pm 1.75$ & $5.82 \pm 2.48$ & -1.249 & 0.217 \\
\hline
\end{tabular}

In single factor logistic regression analysis, only the vel of $0 \mathrm{~h}$-sNGAL and lactate were independent risk factors for death of sepsis within 28 days (see Supplementary Table 2 at https://ojs.ptbioch.edu.pl/index. $\mathrm{php} / \mathrm{abp} /$ ).

When the cutoff of sNGAL-0h predicting 28-day mortality in septic patients was set as $250 \mathrm{ng} / \mathrm{ml}$, sensitivity and specificity were 0.838 and 0.827 , respectively. When the cutoff of lactate predicting 28-day mortality in septic patients was set as $6.6 \mathrm{ng} / \mathrm{ml}$, sensitivity and specificity were 0.892 and 0.653 , respectively. Area under curve (AUC) of ROC curve of sNGAL-Oh was less than that of lactate, so the specificity of sNGAL-0h was better (see Table 4).

\section{Level of PCT, lactate, sNGAL and SOFA score in AKI}

Levels of PCT, lactate and creatine in the serum and SOFA score in sepsis without AKI patients were not significantly different from those of sepsis with AKI patients. However, the level of $0 \mathrm{~h}-\mathrm{sNGAL}$ in sepsis without AKI patients $(217.48 \pm 27.08)$ was lower than that of

\section{Sensitivity and specificity of SNGAL-Oh and lactate predicting 28-day mortality in septic patients}


sepsis with AKI patients $(245.09 \pm 26.03)$, which is significantly different $(p<0.05)$. As the disease developed, the level of 24h-sNGAL and 48h-sNGAL in sepsis without AKI patients $(219.00 \pm 25.66$ and $222.70 \pm 22.16)$ was still lower than that of sepsis with AKI patients $(243.91 \pm 24.65$ and $259.00 \pm 24.36)$, which is significantly different $(p<0.05)$ (see Table 5).

\section{DISCUSSION}

Sepsis, particularly severe sepsis, septic shock and sepsis accompanied by organ failure, has become a major problem in patients in the hospital and their number reaches a million all over the world (Dombrovskiy et al., 2007; Vincent et al., 2009). Some studies have found that dysfunction of organs or cognition of those patients who survived sepsis were considered as a factor that doubled the risk of death during hospitalization within 5 years (Iwashyna et al., 2010; Quartin et al., 1997). Consequently, sepsis and its complications have always been a major public health problem which brings a burden onto the whole society (Moss, 2005). Someone even took sepsis as a hidden disaster of public sanitation (Angus, 2010). In 1980, the initial focus on sepsis was the early stage of inflammation and TNF $\alpha$, IL1 $\beta$ and IL6 were considered to start SIRS. CRP, a group of proteins increasing in the liver by IL6 synthesis, was used as a potential biomarker. At that time, a large dose of glucocorticoids in the regimen was used to treat sepsis (Vandewalle \& Libert, 2020). In 1990, researchers found that PCT levels were elevated in patients with bacterial infections and PCT was then considered as another potential biomarker (Karzai et al., 1997). PCT and CRP can assist in the diagnosis and staging of sepsis, and PCT is a relatively new biomarker but relevant to systemic inflammation, infection and sepsis (Assicot et al., 1993). In comparison to CRP, PCT shows better specificity and is more closely related to prognosis (Cai et al., 2010, Hur et al., 2009). Therefore PCT is now widely used as a biomarker in clinical practice. However, predicting value of PCT is doubtable because of lack of evidence (Karlsson et al., 2010; Kibe et al., 2011). Although no single biomarker proved to be ideal for sepsis over the past three decades, there are at least some biomarkers that can identify critically ill patients, making it possible to provide early diagnose, early treatment, and improved prognosis (Dellinger et al., 2013b).

In all 112 cases enrolled in our study, we checked the level of PCT, lactate and sNGAL, as well as the SOFA score in different groups. The results showed an elevated level of PCT in sepsis patients which suggested an infection by bacteria (Assicot et al., 1993). We also found that as disease has severely progressed, the PCT level increased and the levels of lactate and sNGAl had a similar tendency. Similar results were found in the Haasefielitz and others study (Haasefielitz et al., 2014). Therefore, we can conclude that sNGAL could be used in the risk stratification of sepsis (Wang et al., 2014). Bacterial infection and dysfunction of several organs caused by infection account for that level of sNGAL which increased as the disease developed. Referring to former studies about PCT (Becker et al., 2008; Billeter et al., 2009), we could not set a cutoff for sNGAL in diagnosis of sepsis.

In this study, results suggested that an increased mortality could be related to aging (Hall et al., 2011), accompanied by AKI (Wheeler et al., 2008) and septic shock (Yan et al., 2001). We found that age, level of PCT, lactate, Oh-sNGAL, 24hsNGAL and 48h-sNGAL, as well as the SOFA score were all risk factors for death due to sepsis within 28 days, but only the levels of 0h-sNGAL and lactate were independent risk factors for death of sepsis within 28 days. Similar results were found in the Mikkelsen and others study (Mikkelsen et al., 2009). The levels of 0h-sNGAL and lactate can be used to predict death of sepsis within 28 days and 0h-sNGAL has a higher specificity than lactate.

In comparison to creatine, sNGAL has more value in diagnosis of AKI and similar results were found in the Bagshaw and others study (Bagshaw et al., 2010). In the Hong and others study (Nga et al., 2015), 48-h sNGAL has more value in predicting AKI and similar result was also found in our study.

This study is a single center observation which has a bias during sample collection. The number of sepsis patient cases is not abundant and equivalent among groups.

In summary, sNGAL could be used in risk stratification and prognosis in sepsis patients. The levels of sNGAL and lactate could be single risk factors for death of sepsis within 28 days. In comparison to creatine, 48h-sNGAL has more value in predicting AKI in sepsis patients. However, more studies are needed to provide deeper evidence for these methods.

\section{Declarations}

\section{Ethics approval and consent to participate}

All procedures performed in studies involving human participants were in accordance with the ethical standards of the Institutional Review Board of Ethics Committee of Tongji Hospital and with the 1964 Helsinki declaration and its later amendments or comparable ethical standards. Informed consents to participate were obtained from all participants.

\section{Consent for publication}

Not applicable.

\section{Availability of data and material}

The datasets generated and analyzed during the course of this study are available from the corresponding author on reasonable request.

\section{Competing interests}

The authors declare that they have no competing interests.

\section{Funding}

No funding was received for this study.

\section{Authors' contributions}

Ying $\mathrm{Wu}$ and Chen Yu contributed to the conception and design of the study; Ying Zhou, Zai-Ming He, Wei Zhang contributed to the acquisition of data; Juan Fan and Ying Sun contributed to the analysis of data; Ying Wu wrote the manuscript; All authors reviewed and approved the final version of the manuscript.

\section{REFERENCE}

Angus DC (2010) The lingering consequences of sepsis: a hidden public health disaster? JAMA 304: 1833-1834. https://doi.org/10.1001/ jama.2010.1546

Assicot M, Bohuon C, Gendrel D, Raymond J, Carsin H, Guilbaud J (1993) High serum procalcitonin concentrations in patients with sepsis and infection. Lancet 341: 515-518. https://doi. org/10.1016/0140-6736(93)90277-N 
Bagshaw SM, Haase BM, Fielitz AH, Egi M, Morimatsu H, D'amico G, Goldsmith D, Devarajan P, Bellomo R (2010). Plasma and urine neutrophil gelatinase-associated lipocalin in septic versus non-septic acute kidney injury in critical illness. Int Care Med 36: 452-461. https://doi.org/10.1007/s00134-009-1724-9

Balci C, Sungurtekin H, Gürses E, Sungurtekin U, Kaptanoglu B (2003) Usefulness of procalcitonin for diagnosis of sepsis in the intensive care unit. Critical Care 7: 85. https://doi.org/10.1186/cc1843

Becker KL, Snider R, Nylen ES (2008) Procalcitonin assay in systemic inflammation, infection, and sepsis: clinical utility and limitations. Crit Care Med 36: 941. https://doi.org/10.1097/ CCM.0B013E318165BABB

Behnes M, Bertsch T, Lepiorz D, Lang S, Trinkmann F, Brueckmann M, Borggrefe M, Hoffmann U (2014) Diagnostic and prognostic utility of soluble CD 14 subtype (presepsin) for severe sepsis and septic shock during the first week of intensive care treatment. Crit Care 18: 507. https://doi.org/10.1186/s13054-014-0507-z

Billeter A, Turina M, Seifert B, Mica L, Stocker R, Keel M (2009) Early serum procalcitonin, interleukin-6, and 24-hour lactate clearance: useful indicators of septic infections in severely traumatized patients. World J Surg 33: 558-566. https://doi.org/10.1007/s00268008-9896-y

Bosmann M, Ward PA (2013) The inflammatory response in sepsis. Trends Immunol 34: 129-136. https://doi.org/10.1016/j.it.2012.09.004

Cai L, Rubin J, Han W, Venge P, Xu S (2010) The origin of multiple molecular forms in urine of HNL/NGAL. Clin I Am Soc Nephrol 5 2229-2235. https://doi.org/10.2215/CJN.00980110

Cecconi M, Evans L, Levy M, Rhodes A (2018) Sepsis and septic shock. Lancet 392: 75-87. https://doi.org/10.1016/s01406736(18)30696-2

Cowland JB, Borregaard N (1997) Molecular characterization and pattern of tissue expression of the gene for neutrophil gelatinaseassociated lipocalin from humans. Genomics 45: 17. https://doi. org/10.1006/geno.1997.4896

Dellinger RP, Levy MM, Rhodes A, Annane D, Gerlach H, Opal SM, Sevransky JE, Sprung CL, Douglas IS, Jaeschke R, Osborn TM, Nunnally ME, Townsend SR, Reinhart K, Kleinpell RM, Angus DC, Deutschman CS, Machado FR, Rubenfeld GD, Webb S, Beale RJ, Vincent JL, Moreno R, Surviving Sepsis Campaign Guidelines Committee Including the Pediatric S (2013a) Surviving Sepsis Campaign: international guidelines for management of severe sepsis and septic shock, 2012. Int Care Med 39: 165-228. https://doi. org/10.1007/s00134-012-2769-8

Dellinger RP, Levy MM, Rhodes A, Annane D, Gerlach H, Opal SM, Sevransky JE, Sprung CL, Douglas IS, Jaeschke R, Osborn TM, Nunnally ME, Townsend SR, Reinhart K, Kleinpell RM, Angus DC, Deutschman CS, Machado FR, Rubenfeld GD, Webb SA, Beale RJ, Vincent JL, Moreno R, Surviving Sepsis Campaign Guidelines Committee Including the Pediatric S (2013b) Surviving sepsis campaign: international guidelines for management of severe sepsis and septic shock: 2012. Crit Care Med 41: 580-637. https://doi. org/10.1097/CCM.0b013e31827e83af

Devarajan P (2010) Review: neutrophil gelatinase-associated lipocalin: a troponin-like biomarker for human acute kidney injury. Nephrolog) 15: 419-428. https://doi.org/10.1111/j.1440-1797.2010.01317.x

Dombrovskiy V Y, Martin A A, Sunderram J, Paz H L (2007) Rapid increase in hospitalization and mortality rates for severe sepsis in the United States: a trend analysis from 1993 to 2003. Crit Care Med 35: 1244-1250. https://doi.org/10.1097/01.CCM.0000261890.41311.E9

Feldkamp T, Bienholz A, Kribben A (2011) Urinary neutrophil gelatinase-associated lipocalin (NGAL) for the detection of acute kidney injury after orthotopic liver transplantation. Nephrol Dialys Transplant 26: 1456-1458. https://doi.org/10.1093/ndt/gfr146

Flower DR, North AC, Sansom CE (2000) The lipocalin protein family: structural and sequence overview. Biochim Biophys Acta 1482 9-24. https://doi.org/10.1016/s0167-4838(00)00148-5

Haasefielitz A, Haase M, Devarajan P (2014) Neutrophil gelatinaseassociated lipocalin as a biomarker of acute kidney injury: a critical evaluation of current status. Ann Clin Biochem 51: 335-351. https:// doi.org/10.1177/0004563214521795

Hall MJ, Williams SN, Defrances CJ, Golosinskiy A (2011) Inpatient care for septicemia or sepsis: a challenge for patients and hospitals. Nchs Data Brief 62:

Hur M, Moon HW, Yun YM, Kim KH, Kim HS, Lee KM (2009) Comparison of diagnostic utility between procalcitonin and C-reacive protein for the patients with blood culture-positive sepsis. Korean J Lab Med 29: 529. https://doi.org/10.3343/kjlm.2009.29.6.529 (in Korean)

Iwashyna TJ, Ely EW, Smith DM, Langa KM (2010) Long-term cognitive impairment and functional disability among survivors of severe sepsis. JAMA 304: 1787. https://doi.org/10.1001/jama.2010.1553

Karlsson S, Heikkinen M, Pettilä V, Alila S, Väisänen S, Pulkki K, Kolho E, Ruokonen E, Group FS (2010) Predictive value of pro- calcitonin decrease in patients with severe sepsis: a prospective observational study. Crit Care 14: R205. https://doi.org/10.1016/j. medin.2011.09.008

Karzai MW, Oberhoffer MM, Meierhellmann MA, Reinhart MK (1997) Procalcitonin - A new indicator of the systemic response to severe infections. Infection 25: 329-334. https://doi.org/10.1007/ $\mathrm{BF} 01740811$

Kibe S, Adams K, Barlow G (2011) Diagnostic and prognostic biomarkers of sepsis in critical care. J Antimicrob Chemotherap 66 (Suppl 2): ii33. https://doi.org/10.1093/jac/dkq523

Lambden S, Laterre PF, Levy MM, Francois B (2019) The SOFA score-development, utility and challenges of accurate assessment in clinical trials. Crit Care 23: 374. https://doi.org/10.1186/s13054019-2663-7

Liu T, Chen HW, Liang DY, Hou YQ (2014) Progressof prognostic markers in sepsis. Int J Lab Med 35: 2794-2796

Mikkelsen ME, Miltiades AN, Gaieski DF, Goyal M, Fuchs BD, Shah CV, Bellamy SL, Christie JD (2009) Serum lactate is associated with mortality in severe sepsis independent of organ failure and shock. Crit Care Med 37: 1670-1677. https://doi.org/10.1097/ CCM.0b013e31819fcf68

Mori K, Lee HT, Rapoport D, Drexler IR, Foster K, Yang J, Schmidtott KM, Chen X, Li JY, Weiss S (2005) Endocytic delivery of lipocalin-siderophore-iron complex rescues the kidney from ischemia-reperfusion injury. I Clin Invest 115: 610-621. https://doi. org/10.1172/JCI23056

Moss M (2005) Epidemiology of sepsis: race, sex, and chronic alcohol abuse. Clin Infect Dis 41 (Suppl 7): S490. https://doi. org $/ 10.1086 / 432003$

Nga HS, Medeiros P, Menezes P, Bridi R, Balbi A, Ponce D (2015) Sepsis and AKI in clinical emergency room patients: The role of urinary NGAL. Biomed Res Int 2015: 413751. https://doi. org/10.1155/2015/413751

Passov A, Petäjä L, Pihlajoki M, Salminen US, Suojaranta R, Vento A, Andersson S, Pettilä V, Schramko A, Pesonen E (2019) The origin of plasma neutrophil gelatinase-associated lipocalin in cardiac surgery. BMC Nephrol 20: 182. https://doi.org/10.1186/s12882-0191380-4

Quartin AA, Schein RMH, Kett DH, Peduzzi PN (1997) Magnitude and duration of the effect of sepsis on survival. JAMA 277: 1058

Strehlow MC, Emond SD, Shapiro NI, Pelletier AJ, Jr CC (2006) National study of emergency department visits for sepsis, 1992 to 2001. Ann Emerg Med 48: 326-331. https://doi.org/10.1016/j.annemergmed.2006.05.003

Vandewalle J, Libert C (2020) Glucocorticoids in sepsis: To be or not to be. Front Immunol 11: 1318. https://doi.org/10.3389/fimmu.2020.01318

Vincent JL, Rello J, Marshall J, Silva E, Anzueto A, Martin CD, Moreno R, Lipman J, Gomersall C, Sakr Y (2009) International study of the prevalence and outcomes of infection in intensive care units. JAMA 302: 2323. https://doi.org/10.1001/jama.2009.1754

Wacker C, Prkno A, Brunkhorst FM, Schlattmann P (2013) Procalcitonin as a diagnostic marker for sepsis: a systematic review and meta-analysis. Lancet Infectious Dis 13: 426-435. https://doi. org/10.1016/S1473-3099(12)70323-7

Wang M, Qian Z, Xin Z, Dong G, Li C (2014) Diagnostic and prognostic value of neutrophil gelatinase-associated lipocalin, matrix metalloproteinase-9, and tissue inhibitor of matrix metalloproteinases-1 for sepsis in the Emergency Department: an observational study. Crit Care 18: 634. https://doi.org/10.1186/s13054-014-0634-6

Wheeler DS, Devarajan P, Ma Q, Harmon K, Monaco M, Cvijanovich N, Wong HR (2008) Serum neutrophil gelatinase-associated lipocalin (NGAL) as a marker of acute kidney injury in critically Ill children with septic shock. Crit Care Med 36: 1297. https://doi. org/10.1007/s00134-020-06106-2

Wu J, Hu L, Zhang G, Wu F, He T (2015) Accuracy of presepsin in sepsis diagnosis: A systematic review and meta-analysis. Plos One 10: e0133057. https://doi.org/10.1371/journal.pone.0133057

Yan L, Borregaard N, Kjeldsen L, Moses MA (2001) The high molecular weight urinary matrix metalloproteinase (MMP) activity is a complex of gelatinase B/MMP-9 and neutrophil gelatinase-associated lipocalin (NGAL) modulation of MMP-9 activity by NGAL. J Biol Chem 276: 37258-37265. https://doi.org/10.1074/jbc.M106089200

Zhang A, Cai Y, Wang PF, Qu JN, Luo ZC, Chen XD, Huang B, Liu Y, Huang WQ, Wu J (2016) Diagnosis and prognosis of neutrophil gelatinase-associated lipocalin for acute kidney injury with sepsis: a systematic review and meta-analysis. Crit Care 20: 41. https://doi. org/10.1186/s13054-016-1212-x

Zou Q, Wen W, Zhang XC (2014) Presepsin as a novel sepsis biomarker. World J Emerg Med 5: 16. https://doi.org/10.5847/wjem.j.is sn.1920-8642.2014.01.002 